\title{
Tiedolla on monet kasvot - faktaa ja fiktiota Tieteiden talolla
}

\author{
Kaisu Clarot ja Mervi Miettinen
}

\begin{abstract}
Informaatiolukutaidon työryhmän vuosittainen seminaari veti jälleen runsaasti väkeä Helsingin Tieteiden taloon marraskuussa 2017. Seminaarin teemaksi oli tänä vuonna valikoitunut tiedon moninaisuus: faktat, fiktiot, ja feikkiuutiset olivat Maria Lassila-Merisalon keynote-puheenvuoron ytimessä, ja PechaKucha -esitykset toivat esille uusia näkökulmia niin tekijänoikeuksiin kuin pelillistämiseenkin. Iltapäivän työpajoissa jaettiin kokemuksia hyvistä käytänteistä, ja koko seminaari päättyi Padletille koottuun koosteeseen päivän annista.
\end{abstract}

\begin{abstract}
Koleasta marraskuusta huolimatta Tieteiden talolla kuhisi, kun vuosittainen IL-seminaari pääsi jälleen käyntiin. Päivän ensimmäinen keynoteluennoitsija Maria Lassila-Merisalo, Hämeen ammattikorkeakoulun strategisen viestinnän päällikkö, herätti runsaasti keskustelua ja haastoi yleisöää pohtimaan, mitä me haluamme netistä lukea, kuka tiedon meille tarjoilee, ja miten voimme olla hukkumatta informaatioon (ja miksi pidämme niin kovasti kissavideoista).
\end{abstract}

\section{Kuka luottaisi mediaan?}

Maria Lassila-Merisalon avausluento oli kiehtova katsaus nykypäivän suhteestamme mediaan ja uutisointiin etenkin verkossa. Yhä useampi suomalainen on Lassila-Merisalon mukaan kyynistymässä, ja kokee osaavansa itse parhaiten arvioida uutisten todenmukaisuuden. Valeuutisten aikakaudella, jota kuvastavat MV-lehden kaltaiset sivustot, uutisten julkaisukanavien väliset erot hämärtyvät ja erilaiset uutisia kokoavat verkkosivut nousevat suosiossa.

Informaation luotettavuuteen liittyen Lassila-Merisalo esitteli Tuchmanin objektiivisuuden strategista rituaalia, joka havainnollisti sitä, miten lehtijuttu saattaa objektiivisuuden nimissä esitellä aiheesta kaksi vastakkaista kantaa ja antaa molemmille yhtä suuren painoarvon, vaikka esim. tutkimuksista valtaosa olisi aiheesta toista mieltä ja vain marginaalinen osuus kannattaisi toista kantaa. Esimerkiksi ilmastonmuutoksesta uutisoidessa tämä objektiivisuuden harha tarkoittaa sitä, että vaikka tutkijat ovat lähes yhtä mieltä ilmastonmuutoksesta, lehtijuttu luo kuvan jossa eri osapuolten kannat ovat ns. yhtä vahvoja.

Lassila-Merisalo peräänkuulutti esityksessään

Objektiivisuuden strateginen rituaali (Tuchman) 1972

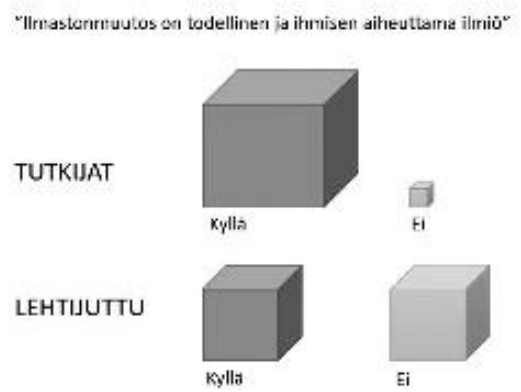

Kuva 1. Lassila-Merisalon esityskalvot, 17.11.2017

lähdekritiikin merkitystä informaatiotulvan keskellä, mutta korosti, että kirjasto ei voi olla yksin vastuussa medialukutaidon opetuksesta. Pohdittavaksi kuulijoille jäikin se, miten voimme ILopetuksen avulla tukea opiskelijoita tunnistamaan faktan fiktiosta ja luotettavan media epäluotettavasta. 


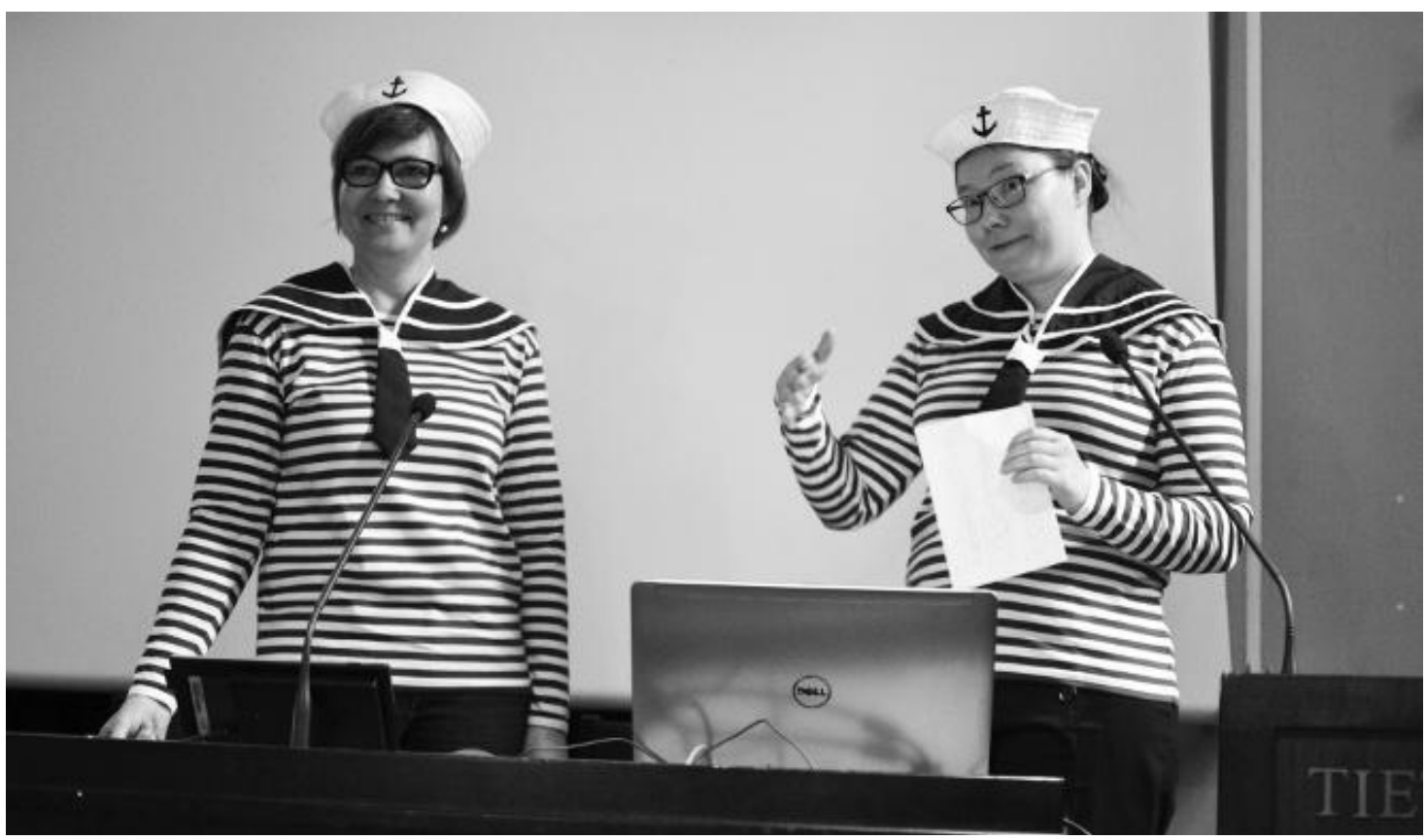

Kuva 2. Annamari Pudas ja Anitta Örn johdattelemassa kuulijoita "Kylmälle keikalle".

\section{Napakkaa ilakointia ja tiukkaa asiaa - PechaKucha-esitykset}

Viime vuodesta hyväksi havaittu PechaKuchaformaatti otettiin osaksi seminaaria myös tänä vuonna. Seminaariin saatiinkin laaja kattaus erilaisia esityksiä, jotka ilahduttivat paitsi napakalla formaatillaan, myös haastavilla ja monipuolisilla aiheilla sekä yhdessä esityksessä myös varta vasten valituilla rooliasuilla. Aiheissa käytiin läpi niin pelillistämistä, MOOCeja kuin käänteistä opetusta, ja monessa esityksessä keskiöön nousi tiedonhankintataitojen ja informaatiolukutaidon opettamisen kehitys.

Tieteellisten seurain valtuuskunnan Anna-Sofia Ruth esitteli pilke silmäkulmassa eri tapoja tunnistaa saalistajajulkaisuja. Saalistajajulkaisujen määrä on vuodesta 2010 moninkertaistunut, joten myös tarve tunnistaa saalistajajulkaisu kasvaa huomattavasti. Saalistajajulkaisuksi (eng. predatory publisher) määritellään lehti, joka rahoittaa toimintaansa kirjoittajamaksuilla, mutta ei noudata hyvää tieteellistä käytäntöä, vaan laiminlyö sille kuuluvat velvollisuudet, kuten vertaisarvioinnin.
Tällaisten lehtien tunnistamiseen Ruthin esitys antoi erinomaiset eväät: $\mathrm{mm}$. hassut nimet ja lyhenteet, suorat yhteydenotot, erittäin laajat aihealueet, epämääräiset verkkosivut ja erilaisten indeksointien esittely ovat ensimmäisiä varoitusmerkkejä. Saalistajajulkaisut tekevät nopeita julkaisupäätöksiä jotka eivät jätä tilaa vertaisarvioinnille.

PechaKuchien kenties hilpein hetki koettiin, kun Lapin korkeakoulukirjaston Anitta Örn ja Annamari Pudas astuivat Tieteiden talon lavalle. Merimieslakit päässä ja sinivalkoiset raitapaidat yllään Örn ja Pudas johtivat koko seminaarin kohti Etelämannerta - pelillistämisen keinoin. Lapin korkeakoulukirjastossa oli kehitetty tarinallistamista ja pelillistämistä hyväksi käyttäen interaktiivinen oppimispeli tiedonhankinnan tueksi.

Kylmä keikka-nimellä kulkeva seikkailupeli antoi makupaloja useamman toimijan yhteistyössä tekemästä pelillistämishankkeesta IL-opetuksessa. Lähdekritiikkiä ja tiedonhankinnan taitoja opettavassa pelissä pelaajat matkaavat tutkimusretkikuntana kohti Etelämannerta ja keräävät tar- 
peellisia varusteita keräämiensä pisteiden avulla. Pelin kehittely oli vielä kesken, joten odotamme innolla miltä valmis peli tulee näyttämään.

\section{Kohti oppijakeskeistä opetusta - Opetusmuodot testissä}

Useammassa PechaKucha-esityksessä tuotiin esille tiedonhankintataitojen opetuksen kehitystä kohti oppijakeskeisempiä malleja, joihin sekä käänteinen oppiminen että MOOCit kuuluvat. Itä-Suomen yliopiston kirjaston ja Kuopion yliopistollisen sairaalan kirjaston Tuulevi Ovaska ja Kirsi Salmi toivat omassa esityksessään esille kokemuksiaan käänteisestä opetuksesta (flipped learning tai flipped classroom). Kuten Ovaska ja Salmi esityksessään totesivat, käänteinen opetus asettaa opiskelijan oppimisen keskiöön, ja mahdollistaa paremmin ongelmaperustaisen oppimisen, joka on etenkin terveydenhoitoalalla suosittu opiskelutapa.

Kokeilussa osa lähiopetuksesta korvattiin itseopiskelumateriaalilla ja ennakkotehtävällä, ja käänteisessä mallissa opiskelleet opiskelijat olivat myös muita paremmin valmistautuneet opetukseen ja pääsivät nopeammin aktiivisen hakemisen vaiheeseen harjoituksissa kuin muut perinteisen mallin mukaan opiskelleet. Esityksessä käytiin läpi opiskelijoiden antamaa palautetta ja kokemuksia uudesta opetusmuodosta, ja vaikka joissain osa-alueissa käänteinen oppiminen koettiin paremmaksi, lopputuloksissa kävi kuitenkin yllättäen ilmi, että oppimistulokset olivat lähes samanlaiset sekä perinteisessä että käänteisessä opetuksessa, eikä selkeää eroa eri opetustapojen välillä löytynyt. Käänteinen oppiminen otti kuitenkin paremmin huomioon yksilölliset erot ja omatahtisen opiskelun, joten se koettiin esityksessä edelleen kokeilemisen arvoiseksi.

Helsingin yliopiston kirjastoa lukuun ottamatta MOOCit eivät ole vielä Suomessa suuremmin lyöneet läpi IL-opetuksessa, mutta Lahden ammattikorkeakoulussa tehty pilotti antoi osviittaa siitä, millainen IL-opiskelu MOOCeilla olisi mahdollista. Essi Prykäri ja Riikka Sinisalo ker- toivat omassa esityksessään, miten LAMKissa oli laadittu MOOC uusien IL-kehysten opiskeluun. Kyseessä oli pilottikurssi korkeakouluopintoja suunnitteleville, ja tavoitteena oli, että kokonaisuuden suoritettuaan opiskelija tunnistaa korkeakouluopintoihin sopivat tiedonlähteet ja ymmärtää tiedon käytön ja tieteellisen viestinnän periaatteet.

\section{Kuvat opetuksessa ja tekijänoikeudet tapetilla}

Tekijänoikeudet nousivat esille seminaarissa useammastakin näkökulmasta. Helsingin yliopiston kirjaston Päivi Helminen johdatteli päivän viimeisessä PechaKucha-esityksessä tekijänoikeuskysymysten haasteisiin opiskelijan ohjauksessa: Helmisen mukaan tekijänoikeusasiat koetaan yleensä tylsiksi, mutta samalla myös vaikeiksi ymmärtää. Ei siis ihme, että sekä opettaja että opiskelija saattavat usein hämmentyä tekijänoikeuskysymysten edessä, ja etenkin kuvien ja muun median kanssa kysymykset tekijänoikeuksista ovat usein vieläkin monimutkaisempia. Erilaisia oppaita ja ohjeita löytyy kyllä, mutta monet niistäkin ovat usein turhan vaikeaselkoisia.

Näihin kysymyksiin toikin vastauksia päivän toinen keynote-puhuja, Aalto-yliopiston tietoasiantuntija Marika Sarvilahti. Sarvilahti toi esityksessään esille sen, miten vahvasti esim. opetusmateriaalit luottavat visuaaliseen informaatioon; kuvien osuus opetusmateriaaleista on jopa $46 \%$. Miten tämä tietoympäristön visualisoituminen on otettu huomioon kirjastoissa ja tiedonhankinnan opetuksessa? Kuvien käyttö selkiyttää opetusta ja välittää informaatiota tekstiä tehokkaammin, mutta esimerkiksi Kopioston digiluvalla käytetyt materiaalit pitää koota suljetulle alustalle opetuksen ajaksi, eikä niitä saa avata laajempaan käyttöön.

Avoimesti on kuitenkin saatavana runsaasti kuvamateriaalia, kuten Sarvilahti esityksessään todisti. Esimerkiksi eurooppalaisen digitaalisen kulttuuriperinnön hyödyntäminen olisi mahdollista, sillä erilaisia taideteoksia, kuten Sarvilahden 


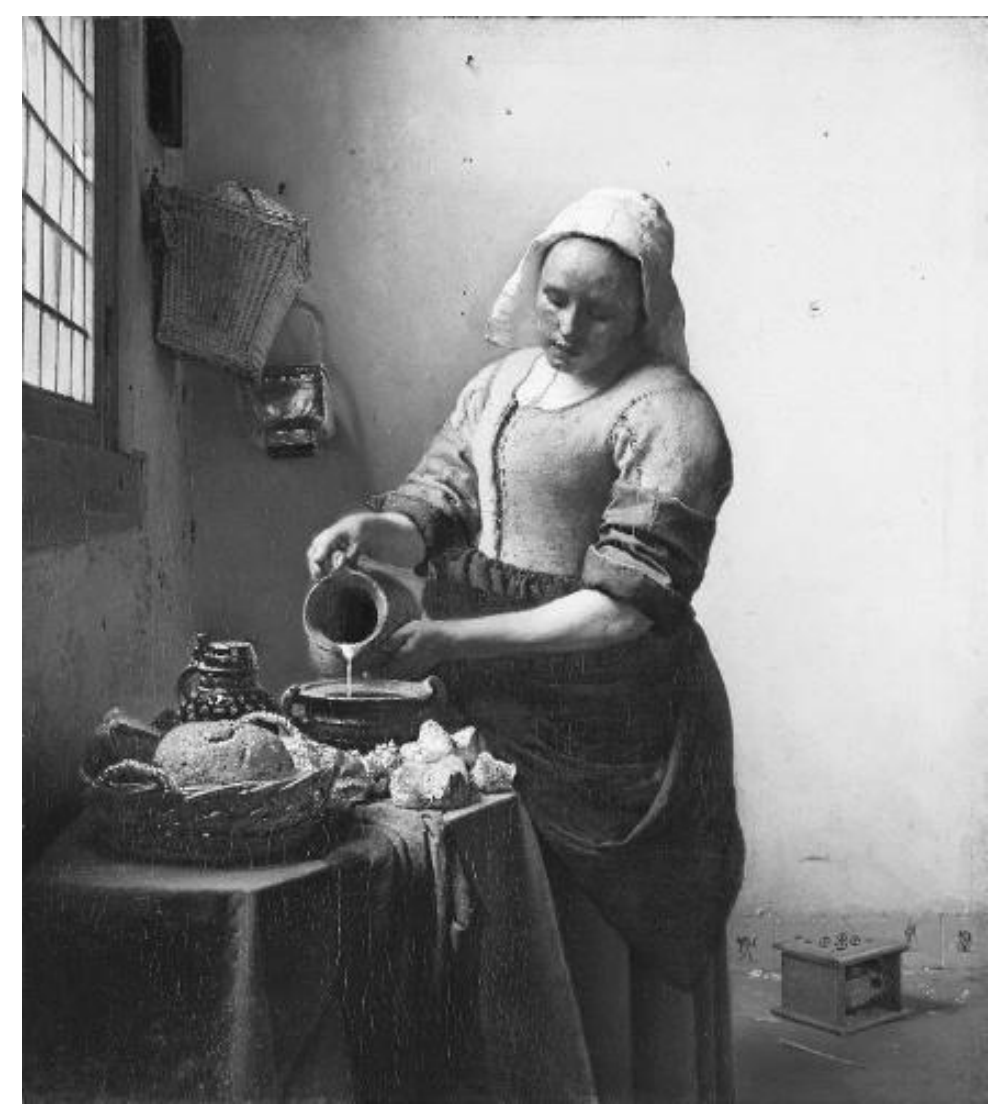

Kuva 3. Johannes Vermeer, The Milkmaid, 1657-1661.

loin sitä saa vapaasti hyödyntää ja kopioida esimerkiksi kirjastojen oppaissa. Oppaan tavoitteena on lisätä yliopistoissa ja ammattikorkeakouluissa luotujen oppimateriaalien avoimuutta ja näin lisätä toiminnan laatua ja yhteiskunnallista vaikuttavuutta, ja mahdollistaa oppimateriaalinen paras mahdollinen hyödyntäminen.

\section{Kirjastot kehyksissä - Uudet IL-kehykset yliopistokirjastoissa}

ACRL esitteli uudet IL-kehykset vuonna 2015, mutta niiden käyttöönottoa ei ole vielä laajalti tutkittu. Kati Syvälahden (Helsingin yliopisto) ja Janika

esimerkkinään käyttämä Johannes Vermeerin The Milkmaid (1660) on muutettu vapaasti käytettävään digitaaliseen muotoon. Sarvilahti listasi esitykseensä useita kuva-aineistotietokantoja, joista olisi mahdollista ottaa käyttöönsä CC-lisensoitua kuva-aineistoa.

Yksi Sarvilahden ehdottama ratkaisu olisi CClisensoidun materiaalien käytön lisääminen juuri opetusmateriaaleissa. Opettajien olisi syytä muutenkin katsoa peiliin, sillä opetusmateriaaleihin jää tälläkin hetkellä turhan usein merkitsemättä esim. kuvien tekijä- ja lähdetietoja. Useimmat opettajat eivät vielä osaa avata omia materiaalejaan avoimilla lisensseillä muiden käyttöön, totesi Sarvilahti.

Sarvilahti on ollut mukana laatimassa uutta, avointa ImagOA-opasta, joka neuvoo avoimeen tieteeseen ja kuvien käyttöön mm. opetuksessa. Opas on lisensoitu CC Nimeä 4.0 -lisenssillä, jol-
Asplundin (Tampereen yliopisto) kyselytutkimus aiheesta onkin ensimmäinen systemaattinen kartoitus IL-kehysten nykytilasta suomalaisissa korkeakoulukirjastoissa. Kyselyssä oli tarkoitus kartoittaa suomalaisten korkeakoulukirjastojen näkökulmia uusiin kehyksiin.

Syvälahden ja Asplundin kyselyn tuloksista paljastui, että lähes kaikki yliopistokirjastot ovat aikanaan pohjanneet opetuksensa vuoden 2000 ILstandardeihin, mutta selvästi alle puolet oli kyselyn tekohetkellä soveltanut uusia kehyksiä tiedonhankinnan opetuksen kehittämisessä. Kehyksissä nähtiin kuitenkin selkeää kehitystä aiempiin standardeihin, ja niitä kuvailtiin mm. työelämälähtöisiksi ja aiempaa laajemmaksi määritelmäksi siitä, mitä informaatiolukutaito nykypäivänä on. Toisaalta kehyksiä myös moitittiin turhan korkealentoisiksi, ja käytännön esimerkkejä niiden soveltamisesta kaivattiin lisää. 


\section{Iltapäivän sadonkorjuu}

Iltapäivän työpajoissa seminaarin väki jakautui useampaan pienryhmään keskustelemaan päivän esityksistä ja jakamaan ideoita ja vinkkejä kotiin vietäväksi. Tässä seminaari hyödynsi Padlet-alustaa, mikä olikin erinomainen ratkaisu - useampi seminaarin osallistuja kehui ottavansa sovelluksen osaksi omia opetuksiaan!

Napakoiden apukysymysten avulla Padletiin saatiin kerättyä osallistujien mielestä seminaarin tärkeimmät annit työhön, linkkejä ja kirjallisuutta esim. visuaalisen tiedon etsimiseen ja tekijänoikeusasioiden opettamiseen - ja kaikki kommentit saimme talteen Padletin avulla.

\section{Loppuun oheislukemistoa ja lähdekirjalli- suutta:}

ImagOA-opas: http://libguides.aalto.fi/imagoa

STKS:n esityssivu:

http://www.stks.fi/asiakirjat/koulutustenmateriaalit/ materiaalit-informaatiolukutaito

Seminaarin Padlet-kooste:

http://www.stks.fi/wp-content/uploads/2017/11/pad let_seminaari_17.11.2017.pdf

\section{Tietoa kirjoittajista:}

Kaisu Clarot, informaatikko

Oulun yliopiston kirjasto

kaisu.clarot@oulu.fi

Mervi Miettinen, koulutuksen tietoasiantuntija

Tampereen teknillisen yliopiston kirjasto

mervi.miettinen@tut.fi 